\title{
The Indo-Pacific in the Strategies of the U.S. and Japan
}

Common and Distinctive Features, Implications for Russia

Anna A. Kireeva

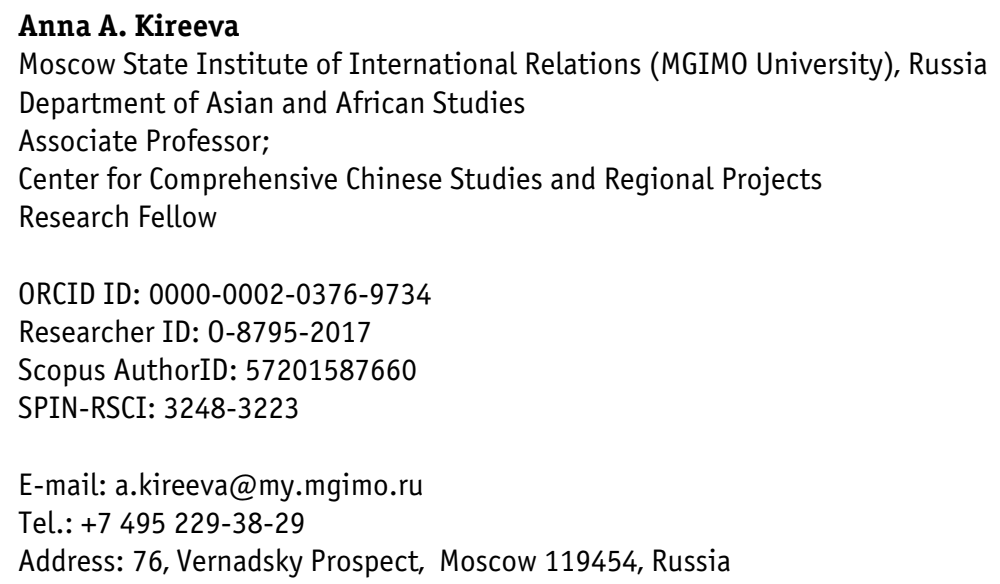

\section{Abstract}

The article seeks to analyze the Indo-Pacific strategies of Japan and the United States as key strategic actors in the region. It identifies their respective goals, how they are stated and what measures are being implemented. Drawing on primary sources in Japanese and English as well as academic literature, the article aims to clarify similarities and differences in the strategies, their distinctive features and how they can be explained. It demonstrates that both states view the Indo-Pacific as a strategic region 
where they would like to see a regional order based on certain rules and principles and free from China's dominance. However, the American strategy has been formulated in a more antagonistic way, focusing on strategic competition, while the Japanese version is milder and employs stronger economic measures. Additionally, the article explores the significance of the findings for Russia's policy in Asia, identifies challenges and opportunities, and proposes a recalibrated course.

Keywords: Indo-Pacific, Russia, Japan, United States, Asia, China, India, ASEAN, Australia, Far East.

\section{INTRODUCTION}

The term 'Indo-Pacific' first appeared in international political discourse in 2007 in an article by Indian researcher Gurpreet Khurana. It was defined as a maritime space connecting the Indian Ocean with the western Pacific which is bordered by all countries in Asia (including West Asia, or the Middle East) and East Africa (Khurana, 2007).

In the 2010s, foreign policy strategies and expert publications in many countries began to pay special attention to the trans-regional area along the coasts of the Indian and Pacific Oceans. Australia for the first time officially included the concept of the emerging IndoPacific in its White Paper in 2013. The emergence of the Indo-Pacific arc connecting the Indian and Pacific Oceans through Southeast Asia was associated with the rise of China and India, their active penetration into neighboring regions, and increased trade, investment and energy flows (Department of Defense, 2013, p.3, 7-8). In 2016 in Nairobi, Japanese Prime Minister Shinzo Abe put forward a strategy calling for a free and open Indo-Pacific region, pointing out that the Indian and Pacific Oceans were interconnected in terms of economy and security (Ministry of Foreign Affairs of Japan, 2016).

Defining the Indo-Pacific as strategically significant is a deeply rooted tradition in India. Speaking during the Shangri-La Dialogue in June 2018, Indian Prime Minister Narendra Modi described it as a naturally formed region that included maritime space from the coast of 
Africa to the coast of America, and noted that India was interested in a free, open, stable, inclusive, safe and prosperous Indo-Pacific region (Ministry of External Affairs, 2018).

In November 2017, addressing an APEC summit in Da Nang, Vietnam, U.S. President Donald Trump for the first time offered his vision of a free and open Indo-Pacific region (The White House, 2017). In American discourse, the Indo-Pacific was conceptualized as a competitive strategic area characterized by unfolding confrontation with China, primarily in the military-political field (Szechenyi, Hosoya, 2019, pp.1-2).

Finally, in June 2019, ASEAN released its Outlook on the IndoPacific. It focused on the creation of an open and inclusive regional order in the Indo-Pacific, including two interconnected regions-the Asia-Pacific and the Indian Ocean region (IOR) - the central position of ASEAN, and mechanisms based on grouping, peace, stability, economic cooperation, and development (Association of Southeast Asian Nations, 2019). Great Britain and France also began eyeing the Indo-Pacific region more closely, getting aware of its importance.

Some governments use the Indo-Pacific concept to define a strategic space where they would like to pursue their own interests. In this regard, two countries are of particular interest: Japan and the United States. Firstly, they have the most conceptualized Indo-Pacific strategies, they are key players in this region, and their policies are largely crucial for the regional order. Secondly, Japan and the United States are connected by a military-political alliance, and the concept of a free and open Indo-Pacific region was proposed by Japanese Prime Minister Shinzo Abe in 2016 and then adopted by the Trump administration in 2017-2018, featuring exactly the same words: a free and open Indo-Pacific (Nakanishi, 2018, p.14). Three questions arise: What do these strategies have in common? What are their distinctive features? What is the reason for the differences in the Indo-Pacific strategies of the two close allies?

The answer to these questions is of great importance for the IndoPacific region since the U.S. and Japanese strategies have a significant impact on the regional order. It is also important for Russia. Foreign 
Minister Sergei Lavrov has repeatedly criticized the Indo-Pacific concept as an artificial creation advanced by the United States, Japan, and Australia in the interests of the former, aimed at deterring China, undermining the central position of ASEAN, and seeking to engage India as well (The Ministry of Foreign Affairs of the Russian Federation, 2019). At the same time, judging by the official statements of the Russian Foreign Ministry, it makes no serious distinction between the American strategy and the strategies of other countries, including Japan and India.

This article aims to compare the Indo-Pacific strategies of Japan and the U.S., determine their common and distinctive features, explain the reasons for the differences, and assess their specifics. In addition, the article will consider the importance and implications of these strategies for Russia. The study is based on a wide range of sources in Japanese and English, primarily U.S. and Japanese conceptual documents concerning Indo-Pacific strategies. In addition, the academic literature and analytical expert comments on key characteristics and effectiveness of the strategies of the two countries appeared to be quite instrumental for the study.

The article is structured as follows. The first and second parts analyze the Indo-Pacific strategies of Japan and the U.S., respectively. The third section summarizes common and distinctive features and explains the differences in the Japanese and American strategies. The final part considers their significance and implications for Russia.

\section{JAPAN'S IND0-PACIFIC STRATEGY}

Japan's strategy for the Indo-Pacific region is based on both structural factors and the important role of the agent. Since the early 2000s, Japan's foreign policy has been influenced, on the one hand, by the growth of Chinese power, especially in the military sphere, with the inability to solve problems in Sino-Japanese relations, and, on the other hand, by the relative decline of the United States' potential and Japan's doubts about American security guarantees in Asia (Suzuki, Wallace, 2018, pp.711-718). In addition, the personality of Japanese Prime Minister Shinzo Abe (Koga, 2020, pp.51-60) also plays a key role. 
The origins of Japan's current Indo-Pacific strategy can be traced back to Prime Minister Shinzo Abe's first term of office in 2006-2007. Speaking in India's Parliament in August 2007, he talked about the "confluence of the two seas"-the Pacific and Indian Oceans-as maritime spaces of freedom and prosperity, where the security of sea lanes is extremely important for both Japan and India. He called for building a broad network that would encompass the entire Pacific Ocean, including the United States and Australia, and would ensure the freedom of movement for people, goods, capital, and knowledge (Ministry of Foreign Affairs of Japan, 2007). In May 2007, Abe's efforts led to the first meeting of the Quadrilateral Security Dialogue (Quad). This format was based on the joint work in the Tsunami Core Group that had coordinated relief efforts after the Indian Ocean tsunami in 2004-2005 (Pajon, 2019). However, the dialogue ceased to exist already in 2008. Five prime ministers changed in Japan between 2007 and 2012.

In December 2012, when Abe took the office of prime minister again, he published an article entitled Asia's Democratic Security Diamond, in which he proposed the concept of a security diamond consisting of Japan, the U.S., Australia, and India as democratic countries that respect the rule of law and human rights, in order to "safeguard the maritime commons stretching from the Indian Ocean region to the western Pacific." China's forceful actions in the East China and South China Seas were criticized as jeopardizing the freedom of navigation and threatening to turn the South China Sea into a "Lake Beijing" (Abe, 2012).

In his speech at the Shangri-La Dialogue in Singapore in May 2014, Abe reiterated the interconnectedness of the Pacific and Indian Oceans. He called for respecting the freedom of navigation and the rule of law in the maritime space, including the need (1) to base territorial claims on international law, (2) to refrain from using force or coercion to drive these claims, and (3) to settle disputes by peaceful means. Although the word "China" was never mentioned in the Japanese prime minister's speech, his criticism of those who sought to change the status quo using force or coercion left little room for doubt (Prime Minister of Japan and His Cabinet, 2014). 
Prime Minister Abe first came up with the idea of a free and open IndoPacific at the 6th summit of the Tokyo International Conference on African Development (TICAD) in Nairobi in August 2016. Abe noted the interconnectedness of the two oceans and two continents-Asia and Africa-and Japan's important role for the prosperity of this region based on the values of freedom, the rule of law, and a market economy free from the use of force and coercion (Ministry of Foreign Affairs of Japan, 2016).

According to Japan's 2017 Diplomatic Bluebook, at a summit in Nairobi, Abe announced the "Free and Open Indo-Pacific Strategy," which highlights two key elements. Firstly, it is free and open seas as a source of peace and prosperity. Secondly, it is the interconnectedness of Asia, the Middle East, and Africa (Ministry of Foreign Affairs of Japan, 2017, p.15-16). The 2018 Bluebook prioritizes a free and open maritime order based on fundamental principles such as the freedom of navigation and the rule of law. Japan seeks to implement its Indo-Pacific strategy by providing the "international public goods" for the stability and development of the region (Ministry of Foreign Affairs of Japan, 2018, p.13). The 2019 Bluebook no longer mentioned "fundamental principles," and the principles themselves were revised to add free trade. It was pointed out that Japan had clarified its position on multilateral platforms and planned to build relations of "multilayered cooperation" with different countries (Ministry of Foreign Affairs of Japan, 2019a, p.24). Since the end of 2018, Japanese officials have been using the term 'vision' instead of 'strategy' in relation to Japanese policy in the Indo-Pacific (Koga, 2020, p.65).

Two aspects stand out quite clearly in Japan's Indo-Pacific strategy: security and economy. In the field of security, the following key features can be distinguished. First, it is the intention to participate in forming and shaping the regional order in the Indo-Pacific as one of the leading regional powers, and to prevent China from changing it in its favor and dominating the region. This goal is closely linked with such aspects of the strategy as support for the freedom of navigation

This term was present only in the English version of the 2018 Diplomatic Bluebook. There is no such term in the Japanese version. 
and the rule of law. According to the Japanese leadership, these are key principles that should underlie the regional order. Japan is seeking, together with other countries, to create an order with such regulatory rules that will allow them to format China's behavior (Koga, 2020, pp. 49-50, 59, 67, 69) and make it less revisionist (Szechenyi, Hosoya, 2019 , pp.3-4). Strategic competition for organizing and reshaping the regional order is one of the key aspects of the Japanese strategy. Japan is interested in preserving the order in which the United States plays the leading role and the rules which were created by the United States (Sahashi, 2019, p.7; Pajon, 2019).

Secondly, it is the deepening of strategic cooperation with countries whose security interests are similar to the Japanese ones, primarily the alliance with the United States (Szechenyi, Hosoya, 2019, p.2). However, due to U.S. President Donald Trump's inconsistent policy regarding commitments to allies in Asia and the relative decline of American power, Japan believes that relying on the alliance alone would not be enough. So Japan seeks to develop cooperation with like-minded countries, such as Australia, India, ASEAN (primarily the Philippines and Vietnam, as well as Malaysia and Indonesia), Great Britain, and France (Koga, 2020, pp.71-72; Pajon, 2019; Wallace, 2018, pp.891-892).

A special role is assigned to cooperation with Australia and India, both bilateral and trilateral with the United States, as well as the Quadrilateral Security Dialogue (Quad) relaunched in 2017. Its participants noted the complementarity of the Indo-Pacific strategies, the general support for a free, open and inclusive IndoPacific and rules-based order, the freedom of navigation and flight, and sustainable development, and agreed to cooperate in the areas of disaster management, WMD non-proliferation, cybersecurity, maritime security and counter-terrorism (Ministry of Foreign Affairs of Japan, 2019b). In September 2019, consultations for the first time were held at the ministerial level. Starting from 2018, all statements have been reiterating the inclusive nature of the Indo-Pacific and articulating support for ASEAN's centrality (Koga, 2020, p.65). Japan's Self-Defense Forces have one of the most powerful naval capabilities in Asia. Since 2017-2018 Japan has been seeking to increase its presence 
by demonstrating the flag, conducting joint exercises, and calling at the ports of partner countries in the Indo-Pacific region.

Thirdly, it is Japan's policy aimed at countering both traditional and non-traditional security challenges and threats and helping other countries strengthen institutions dealing with maritime security, Maritime Domain Awareness, human development, disaster management, counter-piracy, terrorism, WMD non-proliferation, and participation in peacekeeping operations (The Government of Japan, 2019, p.2). Japanese aid is provided through two different channels: the Ministry of Defense and the Official Development Assistance. ASEAN countries have traditionally been the principal recipient, but the geographic coverage of aid programs has recently been expanded to include geostrategic coastal countries in the Indo-Pacific region such as Sri Lanka, Yemen, Oman, Djibouti, Kenya, and Tanzania (Wallace, 2018, pp.889-891).

The economic dimension of Japan's Indo-Pacific strategy is equally important. The economic objectives of improving connectivity in the Indo-Pacific are (1) improving interconnectedness through the construction and modernization of high-quality physical infrastructure; (2) strengthening humanitarian connectivity through education, training and exchanges; (3) enhancing institutional connectivity by harmonizing legislation and common rules through free trade areas, agreements, and economic partnerships. The signing in March 2018 of the Comprehensive and Progressive Agreement for Trans-Pacific Partnership is cited as an example of such harmonization. In total, from 1960 to 2016, Japan provided \$320 billion in ODA aid to Asia, Africa, and Oceania. In 1954-2016, Japan dispatched 168,000 experts and 51,000 volunteers to these countries, and 610,000 of their specialists were trained in Japan (The Government of Japan, 2019, pp.2-3).

One of Japan's main economic goals is to create a viable alternative to China's Belt and Road Initiative so that Indo-Pacific countries could have other opportunities for building their infrastructure (Pajon, 2019). Since Japan is an established player in the Asian infrastructure market, it views the Belt and Road Initiative as a competing project (Freeman, Oba, 2019, p.8). Its concerns are caused by nontransparent conditions and principles on which China implements its projects (Koga, 2020, p.67). 
Several key features can be distinguished in Japan's policy in this field. Firstly, Japan seeks to provide its own high-quality infrastructure conforming to the principles of openness, transparency, economic viability, etc. In May 2015, Japanese Prime Minister Abe announced the "Partnership for Quality Infrastructure," backed by $\$ 110$ billion in funding for infrastructure projects in Asia for five years (2016-2020). In 2016, Japan announced the "Expanded Partnership for Quality Infrastructure" which increased funding to $\$ 200$ billion, broadened the range of infrastructure facilities covered, and expanded it to the whole world. The projects will involve private capital, including through public-private partnerships. Japan implements a large number of infrastructure and industrial projects in Southeast Asia, India, and Bangladesh. In addition, Japan has launched projects in East Africa (The Government of Japan, 2019, pp.4.6-12).

Secondly, Japan is developing cooperation with India, the U.S., and Australia. During Abe's visit to India in May 2017, Japan and India reached an agreement on the joint implementation of the Asia-Africa Growth Corridor project aimed at accelerating growth, increasing connectivity between Asia and Africa, and creating a free and open Indo-Pacific region (Panda, 2017, pp.1-9). In 2018, Japan signed bilateral and trilateral cooperation agreements with the United States and Australia to build high-quality infrastructure, and improve energy and digital connectivity (Koga, 2020, p.67).

Thirdly, Japan is considering ways to limit its cooperation with China in the field of infrastructure development. In October 2018, during Prime Minister Abe's visit to Beijing, the two countries held the first Market Cooperation Forum, signing 52 agreements of intent worth about \$18 billion for infrastructure construction in third countries. Japan hopes that apart from business contracts, the participation of its companies will help improve the feasibility of infrastructure projects due to their higher quality and transparent business models. This, in turn, should help Japan influence the implementation of the Chinese initiative (Pajon, 2019), and possibly even find ways to coexist with it (Kawashima, 2018, p.32).

How can the Japanese strategy be assessed? Since the end of 2018, the Japanese prime minister has been officially using the term 'vision' 
or 'concept' instead of the Indo-Pacific 'strategy', so that any possible allusion to military strategy would not ruin efforts to improve relations with China. In 2017-2018, the Japanese government changed rhetoric and softened the wording in the Indo-Pacific strategy, emphasizing its inclusiveness and cooperative nature (Hosoya, 2019 Pajon, 2019; Sahashi, 2019). The administration is trying to find a balance between strategic competition and cooperation with China (Szechenyi, Hosoya, 2019, pp.3-4). The transformation of Japan's strategy was also prompted by concerns in ASEAN countries about its anti-Chinese and confrontational nature. So Japan has stopped emphasizing fundamental values such as democracy and human rights in order not to antagonize Thailand, Vietnam, and Myanmar among others. Similarly, the Quad's statements now clearly articulate support for ASEAN's central position in response to concerns of its member countries that they would be marginalized (Koga, 2020, pp.65-66; Pajon, 2019; Szechenyi, Hosoya, 2019, p.4; Hosoya, 2019, p.23).

On the one hand, Japan's more flexible approach to formulating the Indo-Pacific strategy allows it to use conceptual uncertainty in order to modify it, taking into account the reaction of other states. If the concept is able to incorporate the preferences of different states, including those that have strong political and economic ties with China, it could become the basis for a common vision of the regional order in the Indo-Pacific (Koga, 2020, p.51). However, it is hardly possible to organically combine the views of the Trump administration and ASEAN. Furthermore, increasing strategic competition in the IndoPacific between the United States and China puts Japan in a position where it will be more inclined to support its ally mainly due to the value of American security guarantees (Nakanishi, 2018, p.19). It is highly unlikely that China will overhaul its strategy amid full-scale strategic rivalry with the United States in all areas of bilateral cooperation. Finding ways to coexist with China and achieving a balance in the U.S.-Japan-China triangle is a key challenge for Japan (Kawashima, 2018, pp.32-34).

Japan seeks to build coalitions on specific issues depending on resources, geographical location, interests and priorities of various 
states (Koga, 2020, p.67), and avoids more institutionalized formats or blocs in order not to antagonize China (Hosoya, 2019, pp.24-25). However, there is no consensus in Japan on what exactly a free and open Indo-Pacific region means, and the strategy itself contains many uncertainties (Szechenyi, Hosoya, 2019, p.1; Nakanishi, 2018, p.18-19). This particularly concerns security measures, including those regarding China, outside Japan's immediate geographic environment where its deterrence potential is concentrated. Japan's presence in the South China Sea, and even more so in the Indian Ocean, is sporadic, and there are big obstacles to increasing it (Wallace, 2018, p.887).

In general, the Japanese strategy in the Indo-Pacific region is both competitive and cooperative, but largely competitive as far as China is concerned (Koga, 2020, p.50). Japan seeks to diversify its political and security ties and to create a regional and security environment in which it could secure its strategic autonomy. Japan's strategy is flexible and "multi-layered" and includes various security and economic measures, both on a multilateral and inclusive basis, and in minilateral groups. While maintaining a wide variety of options, Japan is determined to play a role in designing a new order in the Indo-Pacific region as one of the key centers of power (Pajon, 2019).

The economic effectiveness of Japan's Indo-Pacific strategy, on the contrary, is quite high, as it is linked quite closely to its foreign economic strategy. Japanese companies are deeply integrated into regional production networks as technological leaders and manufacturers of high-tech components and intermediate goods. Japan is a key investor in ASEAN countries (Freeman, Oba, 2019, p.10). It seeks to take the niche of high-quality infrastructure construction and to benefit from expanding its economic activities in developing countries, which, on the one hand, can generate new demand through new orders for Japanese companies, the sale of Japanese goods and the provision of services, and, on the other hand, host production facilities at lower costs as an alternative to China (Wallace, 2018, pp. 893-897, 901-902).

However, the future of Japan's joint initiatives with partners is not so clear. The problem with the Asia-Africa Growth Corridor is that it does 
not have a single decision-making center, it is not clear what funding it will attract and on what terms, and the project itself is still at a fledgling stage. This makes one wonder whether countries can really offer a robust economic alternative to the Chinese Belt and Road (Panda, 2017, p.9). As for other formats with the United States and the United States and Australia, it is not yet clear how broad this cooperation will be.

\section{THE U.S. INDO-PACIFIC STRATEGY}

Secretary of State Rex Tillerson was the first in the Trump administration to have spoken about a free and open Indo-Pacific region. Speaking about relations with India at the Center for Strategic and International Studies (CSIS) in October 2017, he noted that the United States and India shared a commitment to the rule of law, freedom of navigation, free trade and universal values, and should contribute to development, stability and security in a free and open Indo-Pacific region (Center for Strategic and International Studies, 2017). In his speech at the APEC summit in Da Nang in November 2017, U.S. President Donald Trump called for making a choice in favor of a free and open Indo-Pacific region (The White House, 2017).

The 2017 National Security Strategy and the 2018 National Defense Strategy designated China, along with Russia, as a key strategic security threat and strategic competitor. The documents said that a new era of rivalry between the great powers was beginning: China is building up military capabilities, increasing its influence at the expense of other countries' sovereignty, using "predatory capitalism," economic incentives and coercive measures, and spreading authoritarianism in order to forcefully restructure the order in the Indo-Pacific region. The goal of China's military modernization is to achieve regional hegemony in the Indo-Pacific region in the short term, and replace the United States as a global hegemon in the long term. China is accused of undermining the world order from within, of benefiting from it while at the same time discrediting its principles and norms, and of conducting activities in the South China Sea that threaten free trade, and undermine the sovereignty of other countries and regional stability (President of the United States, 2017; U.S. Department of Defense, 
2018). In May 2018, the United States symbolically changed the name of its Pacific Command to Indo-Pacific Command.

U.S. Vice President Mike Pence's strong anti-Chinese speech at the Hudson Institute in October 2018 became a kind of watershed in American policy. He accused China of using a whole arsenal of measures that are incompatible with the principles of free and fair trade: tariffs, quotas, currency manipulations, forced transfer of technology, theft of intellectual property, industrial subsidies; of building military capabilities to impair the American military advantage on land, at sea, in the air and space; of seeking to "squeeze" the United States out of the western Pacific and preventing it from coming to the rescue of its allies; of building a police state, restricting access to information, limiting the freedom of conscience; and of using "debt diplomacy" to expand its influence, etc. (Hudson Institute, 2018).

In June 2019, the Department of Defense released the Indo-Pacific Strategy Report. It notes the important role of the Indo-Pacific as the most significant region in the world. A free and open Indo-Pacific is based on the following principles: (1) respect for sovereignty and independence of all nations; (2) peaceful settlement of disputes; (3) free and fair trade on the principles of reciprocity, open investment, transparent agreements and connectivity; and (4) adherence to international norms and rules, including the freedom of navigation and flight. The strategy criticizes China's actions as revisionist and for the first time mentions Russia as a "malign" actor (The Department of Defense, 2019).

In November 2019, the State Department released its own strategy for a free and open Indo-Pacific region. It says that the significance of the region for the United States stems from a trade turnover of \$1.9 trillion, the presence of allies outside NATO and the status as the main donor of economic assistance, which has exceeded $\$ 2$ trillion since World War II. The document names such priorities as strengthening relationships with partners and regional institutions, economic prosperity, improved governance, peace and security, and investment in human capital (Department of State, 2019).

In May 2020, the White House released a report titled "U.S. Strategic Approach to the People's Republic of China" describing the U.S. 
strategy towards China. It accuses the Chinese Communist Party of exploiting the free and rules-based order and attempting to reshape it in its favor, and clearly articulates economic, security and value challenges. In order to protect the U.S., promote its prosperity, achieve peace through strength and advance American influence, the report rolls out a competitive approach towards the PRC aiming to improve the resilience of institutions, alliances and partnerships, as well as to compel China to cease or reduce actions deemed harmful to the national interests of the U.S. or its allies and partners. The document suggests that strategic competition is going to be the dominant approach for the years to come (The White House, 2020).

The following features can be distinguished in the American Indo-Pacific strategy. In the field of security, firstly, the recognition of China as a key strategic competitor and opposition to its attempts to change the regional order are at the heart of the American strategy. The emphasis on the Indo-Pacific as a priority region for the United States is prompted precisely by the need to prevent China from becoming a dominant regional power, which may lead to the loss of the U.S. dominant position in the world (Tellis, 2020, pp.11.39). This explains the American administration's commitment to promoting an open and free Indo-Pacific region, and an order based on rules and international law. The Trump administration understands rules as the freedom of navigation and flight, support for sovereignty, which means that there should be no Chinese intervention, and the key role of market principles and private investment (Manning, 2018, p.8).

The United States aims to prevent China from controlling the Asian periphery (Tellis, 2020, p.30-31) and realizing anti-access/area denial (A2/AD) strategy within the first island line, which would significantly increase the cost of U.S. participation in military operations (Manning, 2018, p.9). In order to increase deterrence, the United States continues to build up its military capabilities in the Into-Pacific region both on its own territory (Guam Island) and on the territory of its allies, by deploying advanced long-range weapons, especially sea-based and airborne ones, and employing new technologies (stealth, hypersonic, drones), as well as carrying out operations to maintain the freedom 
of navigation operations (FONOP) in the South China Sea. The emphasis is on mobility, expanding the presence, improving logistical connectivity, conducting multi-domain operations, and selling advanced weapons to allies (The Department of Defense, 2019). After the expiration of the INF Treaty in August 2019, U.S. Secretary of Defense Mark Esper supported the deployment of land-based mediumrange missiles in Asia in order to strengthen the deterrence potential against China. Furthermore, following the erosion of American military superiority in the region, the National Defense Authorization Act for Fiscal Year 2021 introduces a Pacific Deterrence Initiative intended to prioritize the Indo-Pacific and focus resources on key capability gaps in order to win wars and increase deterrence capabilities vis-à-vis China. It also seeks to reassure allies and partners of the U.S.' commitment to the region following Asia Reassurance Act adopted by the Congress in December 2018 that outlined U.S. interests and policy priorities to reassure its allies (Inhofe and Reed, 2020).

Secondly, the United States seeks to increase interoperability and complement its capabilities with a network of alliances and partnerships, including trilateral partnerships and ties between allies (Japan, South Korea, Australia, the Philippines, Thailand) and partners (Taiwan, ASEAN and South Asia, Great Britain, France, and Canada) (The Department of Defense, 2019). The U.S. wants other IndoPacific countries to assist it in countering China, do it individually and jointly, thus sharing the costs and lifting part of the burden off the U.S.s shoulders, which would allow it to use its limited resources more efficiently and increase the multiplicative effect from cooperation (Istomin, 2019, p.16). Strengthening military and political cooperation with India in order to pull it to its side in confrontation with China is one of the main features of the American policy in the region (Istomin, 2019, pp.12-13; Manning, 2018, p.3).

Thirdly, the United States has placed greater emphasis on strengthening the ability of countries in the region to respond to security threats. Every year, the U.S. conducts about 90 military exercises in the region. Some of them are aimed at countering nontraditional challenges and security threats, and others address military 
threats (The Department of Defense, 2019, p.29). In particular, the U.S. is developing such cooperation with Vietnam, the Philippines, Malaysia, and Indonesia in order to help them resist China's actions in the South China Sea (Manning, 2018, p.10). In 2016, the United States passed the Asia-Pacific Maritime Security Initiative Act, which envisaged a five-year program to help counter maritime security threats. In 2019, the geographic coverage of the Initiative was expanded to the Indo-Pacific region and extended until 2025 (The Department of Defense, 2019, p.49).

Fourthly, speaking at the APEC Business Summit in November 2018, U.S. Vice President Mike Pence announced the Indo-Pacific Transparency Initiative with a total budget of $\$ 600$ million, aimed at helping to form civil society, and transparent and accountable governments to support the rule of law and improve the quality of public administration. In November 2019, an additional $\$ 68$ million were allocated for the same purpose (Department of State, 2019, p.21).

The United States also adopted a number of economic measures related to economic assistance and infrastructure support. In October 2018, the BUILD Act was passed to improve the use of investment for development, which presupposes the creation of the U.S. International Development Finance Corporation (DFC) by consolidating and expanding the functions of institutions already operating in this field: the Overseas Private Investment Corporation (OPIC) and partly the U.S. Agency for International Development (USAID). The new corporation was created in December 2019 with a total budget of $\$ 60$ billion. Its purpose is to encourage private investment projects as an alternative to projects implemented by state-owned Chinese companies, thus increasing America's influence in developing countries. The corporation plans to attract $\$ 12$ billion in private investments in the next five years (Department of State, 2019, pp.15-16).

In addition, the United States has launched a number of new initiatives such as the Infrastructure Transaction and Assistance Network (ITAN), which provides legal advisory services and technical assistance in assessing potential infrastructure projects, the Digital Connectivity and Cyber Security Partnership, U.S.-ASEAN Smart 
Cities Partnership, the Asia EDGE (Enhancing Development and Growth through Energy) program aimed at creating sustainable and secure energy markets, and additional ASEAN and Indo-Pacific assistance programs worth $\$ 100$ million (Pacific Pledge). The United States seeks to increase economic support and assistance to developing countries, especially ASEAN states, in order to provide them with an alternative to Chinese projects. In addition, the goals include improving American companies' access to markets, creating a level playing field for them, expanding economic ties with the region, and increasing the export of goods and services (Department of State, 2019, pp.10-19).

How can the American strategy be assessed? The main change that distinguishes the Indo-Pacific strategy from the strategies adopted by previous administrations is the transformation of the U.S. policy towards China (Economy, 2019; Istomin, 2019; Manning, 2018; Tellis, 2020). The United States has developed a rare bipartisan consensus on strategic confrontation with China as the main competitor in almost all areas: politics, security, economy, technology, ideology, and values. China has begun to be considered a key threat to the American state and society, with not only the White House, but also Congress being actively involved in developing measures to counter China. In 20182019 the Trump administration started a trade war with China and economic and technological decoupling (Economy, 2019).

Previous U.S. administrations assumed that encouraging China's integration into the world economy and the world system as one of its stakeholders, supported by strong alliances and partnerships and a military presence in the Asia-Pacific region, would help preserve the global liberal order, with the U.S. playing the leading role, and contribute to the liberalization of both the economic and political system in China (Economy, 2019; Manning, 2018, p.3; Tellis, 2020, pp.5-6). But in 2008-2009 China started to implement a more assertive policy, subsequently launched the Belt and Road Initiative, and announced the "Made in China 2025" strategy, which added economic and technological challenges to the already existing security ones. The growth of China's military power, coupled with its intention to reshape the regional and world order, where the United States is seeking to 
maintain its dominant position, spurred strategic rivalry. By the end of Barack Obama's second term, China had been able, through incremental measures, to gradually change status-quo and realize its interests, especially in the East China and South China Seas, at the expense of the United States and its allies without any serious negative consequences for itself. It became obvious that the policy of engaging China and trying to find compromises did not work (Economy, 2019; Sutter, 2018, pp.5-9, 145-164; Tellis, 2020, pp.6-7, 11, 18, 21). The antagonistic course was also prompted by Trump's personal views. He had been opposed to China in the economic sphere from the very start, and, while in office, saw no changes in China's policy (Harding, 2019, p.63; Tellis, 2020, pp.22-24).

At the same time, with the exception of policy towards China and North Korea, the goals of the Indo-Pacific security strategy and the means of its implementation are based on the Obama administration's Rebalance to Asia-Pacific policy and demonstrate a high degree of continuity with regard to the region. Examples include deepening relations with allies (Japan, South Korea, Australia) and partners (India, ASEAN) (Harding, 2019, p.65).

There are a number of issues and problems related to the American strategy. Firstly, countries in the region do not want to choose one of the sides in the confrontation between the United States and China. The latter is the main economic partner for almost all Asian countries, including American allies, and they do not want to get involved in the same strategic confrontation with China and break economic ties with it (Freeman, Oba, 2019, p.7; Green, 2019; Manning, 2018, p.12; Tellis, 2020, pp.32, 42). Secondly, some aspects of Trump's policy meet a negative reaction from allies: doubts about the utility and relevance of alliances and American commitments to them, U.S. determination to put pressure on allies in order to increase their defense spending and equalize the trade balance, the U.S. withdrawal from the Trans-Pacific Partnership, disregard for multilateral institutions and regional platforms, and lack of support for the liberal international order (Green, 2019; Harding, 2019, pp.6555; Tellis, 2020, pp.41-43). 
Thirdly, the U.S. strategy is just beginning to take shape and measures to implement it are not clearly defined yet. The measures being taken are inconsistent and priorities are uncoordinated (Green, 2019). The bureaucratic organization of the new policy is also complex, taking into account the need for joint work of various departments and agencies overseeing different regional segments. It is not clear how much of the military potential, including new weaponry, will be relocated to the region (Istomin, 2019, pp.25-28). Likewise, there is no clarity about Washington's ultimate goal in its competition with China, what the rules of the game are, where cooperation is possible and what measures the United States considers necessary for its allies and partners to take. Finally, it is not clear how far the United States is ready to go in opposing China and breaking economic ties with it, to what extent American business is going to follow suit and decouple from the Chinese market, and what price American society will be ready to pay for full-scale rivalry (Green, 2019; Tellis, 2020, pp.39-43). Fourthly, there are doubts that, given the amount of funding pledged, the economic measures taken by the United States will be sufficient to present a real alternative to the Belt and Road Initiative (Harding, 2019, p.64; Istomin, 2019, pp.30-31).

\section{COMMON AND DISTINCTIVE FEATURES IN THE AMERICAN AND JAPANESE INDO-PACIFIC STRATEGIES}

Based on the analysis above, the following are common features of the U.S. and Japanese Indo-Pacific strategies.

Firstly, both countries are aware of, and clearly articulate, the important role of Indo-Pacific in terms of regional order, security, and economy. Their adoption was influenced by both structural factors and the role of agents (Abe and Trump). In implementing their strategies both countries focus on the Asian segment of the Pacific and parts of South Asia, especially India. Japan and the United States seek to strengthen partnerships with more or less the same countries: Australia, India, ASEAN countries, especially Vietnam, the Philippines, Malaysia, and Indonesia (Green, 2019).

Secondly, both strategies are based on their respective countries' current foreign and foreign economic policies and include previous 
initiatives and approaches. They provide a common framework, or umbrella, for all policies towards the Indo-Pacific (Nakanishi, 2018, pp.15-16; Harding, 2019, p.65).

Thirdly, both countries are facing a dilemma: on the one hand, they have mutually beneficial relations of economic interdependence with China, but on the other hand, they are worried by its increasingly assertive security and economic policy, which can lead to the emergence of a Chinese-centric order. Neither country wants China to become the dominant power in the region (Szechenyi, Hosoya, 2019, p.2). Despite positive dynamics in relations between Japan and China in 2017-2018, there are no major changes in their strategies, and strategic competition between them continues (Kawashima, 2018).

Fourthly, maritime security in the Indo-Pacific is important for both Japan and the U.S. because of large volumes of trade by sea. It is also associated with combating non-traditional security challenges and threats such as disaster relief, transnational crime, piracy, terrorism, etc. The policies of both countries are aimed at improving the capacity building of Indo-Pacific countries, especially ASEAN states, to help them better cope with the challenges (Szechenyi, Hosoya, 2019, p.5).

Fifthly, neither Japan nor the United States has proposed any new institutions to advance their strategies, except for the restored Quad which up to date does not go beyond consultations between government officials and ministers. Both countries prefer flexible interaction in bilateral, trilateral, and minilateral formats rather than inclusive and institutionalized multilateral contacts. The former allows them to develop cooperation of different types and intensity, find more areas of common interest and take action from time to time, thus creating a flexible network of partnerships and coalitions (Istomin, 2019, pp.22-23; Pajon, 2019).

Sixthly, both countries see the need to provide an alternative to China's infrastructure projects, and having adopted a number of government support measures, they are seeking to engage their private sectors as well. They stand ready to support developing countries, especially ASEAN states, so that they could improve the quality of projects and avoid falling into debt traps or economic dependence on 
China. These measures are also designed to strengthen the position of their own businesses in the Indo-Pacific markets, while at the same time helping achieve their economic interests.

Let us now take a look at the distinctive features of the two countries' Indo-Pacific strategies. The key distinction lies in different policies towards China: the Japanese strategy is softer, while the American one is more antagonistic (Szechenyi, Hosoya, 2019, p.1; Sahashi, 2019, p.7). Unlike the United States, Japan does not view relations with China as a zero-sum game, and, while teaming up with America in countering China in the field of security, seeks stable relations with China and tries to find ways to coexist with it in the economic sphere, including the Belt and Road Initiative. The reason for the different attitudes is that Japan is much closer to China geographically than the United States is (Nakanishi, 2018, p.18; Kawashima, Kamiya, Schoff, 2019, pp.1-2), and it does not have enough military capabilities to use in the event of a full-scale military conflict with China. Japan's self-defense forces lag significantly behind other armies in terms of offensive capability (including the missile one) and ability to project force outside the country (Shimodaira, 2018, pp.48, 141-142). There is close economic interdependence between Japan and China, allowing many Japanese companies to develop successful business models. Japan is not ready for economic decoupling from China, which will damage its production chains, and opposes anti-Chinese economic measures taken by the Trump administration (Kawashima, Kamiya, Schoff, 2019, pp.1-2). As a result, Indo-Pacific countries are more ambivalent towards the American strategy, since many of them, like Japan, are not ready to sour relations with China.

Secondly, the two strategies have different geographical scopes. The American strategy describes the Indo-Pacific as a region stretching from the west coast of the United States to the west coast of India (The Department of Defense, 2019, p.1). In Japan's understanding, the IndoPacific includes the Asian part of the Pacific, the Indian Ocean, Asia, and Africa. The fact that the American strategy is limited to the western part of the Indian Ocean is viewed as its weakness.

Thirdly, in implementing its Indo-Pacific strategy, the United States relies mainly on military-political tools and allocates much less funding 
for infrastructure and economic development assistance programs than Japan. Tokyo, on the contrary, places much greater emphasis on economic measures. The reason is both Japan's lack of material resources in the military sphere and the need to concentrate them in the southwest in the event of a military conflict with China, as well as constitutional restrictions on the use of armed force abroad and reluctance to pursue such a policy due to weak support from Japanese society and the risk of meeting China's response in the East China Sea. Economic incentives, on the contrary, perfectly fit into Japan's regional economic strategy aimed at remaining an economic and technological leader occupying top position in production networks (Wallace, 2018, pp.887-888).

Fourthly, the strategies vary in terms of elaboration. The Japanese strategy is an attempt to realize the long-term vision of the Japanese prime minister, who has been in power since December 2012 (Hosoya, 2019, pp.18-19). The American strategy began to take shape in 2018, and conceptual documents were issued in 2019. Although the general outlines are clear, both the set of specific measures for implementing the strategy and priorities remain unclear.

Fifthly, the U.S. and Japanese trade agendas also differ significantly. The Trump administration has withdrawn from the TPP, and emphasized "free and fair" trade, bilateral trade agreements, and trade deficit adjustments. Japan, on the contrary, has succeeded in renewing the Comprehensive Progressive Agreement for Trans-Pacific Partnership and, instead of the United States, is now promoting free trade principles and the conclusion of "high standard" FTA agreements (Szechenyi, Hosoya, 2019, pp.4).

\section{SIGNIFICANCE OF IND0-PACIFIC STRATEGIES FOR RUSSIA}

The Russian Foreign Ministry has assumed a critical position with regard to the Indo-Pacific strategies, stating that they do not help build an open and democratic region, but instead create new dividing lines, increase strategic rivalry, contain China, sideline ASEAN in the regional architecture, and move away from consensus-seeking forms of interaction (The Ministry of Foreign Affairs of the Russian 
Federation, 2020). Russia views the Indo-Pacific negatively, as an echo of U.S.-sponsored alliances of the Cold War era, which have become multilateral and seek to contain China and Russia (Koldunova, 2019).

On the one hand, negative consequences for Russia's position in Asia are obvious. Firstly, increased strategic competition and polarization of the regional order will make it more difficult for Russia to implement its strategy in Asia and expand cooperation with countries which have serious conflicts between themselves: China and India, China and Vietnam (Istomin, 2019, p.38). Secondly, Russia advocates the creation of a "comprehensive, open, transparent and equitable security and cooperation architecture on a collective basis" in the Asia-Pacific region (The Ministry of Foreign Affairs of the Russian Federation, 2016). The interests of Moscow as a weaker major player in the region are negatively affected by the weakening of ASEANbased multilateral organizations. This may ultimately lead to the marginalization of its position in the Indo-Pacific (Tsvetov, 2018).

Thirdly, unstable security environment and military buildup by almost all countries in the region increase security risks for Russia, primarily for its Far Eastern and Arctic regions. This will make it even more requisite for Russia to strengthen its military potential in Asia notwithstanding the difficulties of distributing conventional armed forces between the two main theaters of operations (Istomin, 2019, p.38). As a result, the security dilemma between the United States and Russia may only worsen and acquire a strong Asian dimension in addition to the Euro-Atlantic one. Of particular concern to Russia is the deployment in Asia of regional segments of the U.S. global missile defense system and possible deployment of medium-range missiles in the region after the end of the INF Treaty (President of Russia, 2019).

On the other hand, despite these challenges, the emerging picture is not so simple. Firstly, the U.S. Indo-Pacific strategy is aimed at opposing China, not Russia. When formulating its strategy, the Washington either does not pay attention to Moscow at all, or considers it a marginal player in the region, and not its primary target (Istomin, 2019, p.37). As Sino-American contradictions increase, the U.S. will concentrate its main resources in the littoral Indo-Pacific, which may 
slightly reduce pressure on Moscow and allow it to implement its Eurasian project meeting less resistance (Tsvetov, 2018).

Secondly, there are differences between the American Indo-Pacific strategy and the Japanese one, as well as those of other regional players. Most of them do not want to see China as the dominant power but seek to maintain stable relations and economic cooperation with it. At the Eastern Economic Forum in September 2019, Japanese Prime Minister Shinzo Abe and Indian Prime Minister Narendra Modi tried to find ways to cooperate with Russia, taking into account their own Indo-Pacific strategies. Modi proposed making the Far East a point of contact between the EAEU and an open and inclusive IndoPacific region by creating new trade and logistic routes. Abe suggested connecting the free and open Indian Ocean and Asia with the Russian Arctic strategy and the Arctic Ocean through the Far East and the supply of Arctic LNG to Asian markets (President of Russia, 2019). India and ASEAN's Indo-Pacific complement Greater Eurasia rather than oppose it (Kuprianov, 2018).

The reason for stepping up Russian policy in this area is the fact that, despite close political and military cooperation with China, it is the role of one of the stakeholders in the polycentric order, rather than a hierarchical China-led order in Asia, that is more consistent with Russian interests in this part of the world. Most regional players have already devised their Indo-Pacific strategies, and if Russia remains passive, the region will develop without it and contrary to its interests, even though geographically it is a northern Pacific power (Kupriyanov, 2018). At this point, the Quad is unlikely to turn into an "Asian NATO," primarily due to India's position (Tsvetov, 2018). However, Moscow's constant criticism of the Indo-Pacific is viewed by most regional players as counterproductive. It cannot change their positions, but only harms bilateral relations, especially with India and Vietnam, and also becomes another irritant in relations with Japan. Active criticism may lead the United States to start opposing Russia in Asia more actively (Istomin, 2019, pp.39-40).

The best Russia can do in this situation is to remain, as much as possible, a neutral player in the Sino-American strategic competition in the Indo-Pacific, retain its strategic autonomy (Istomin, 2019, p.40), 
formulate a clear and attractive agenda for Asia (Tsvetov, 2018), and expand cooperation with Asian countries in any format, including the Indo-Pacific one. Firstly, it would be appropriate to support the inclusive nature of the Indo-Pacific and the strategies of the countries that advance such a vision (primarily India and ASEAN countries), as well as to refrain from criticizing the approaches of states that indicate, at least declaratively, their commitment to an open and inclusive Indo-Pacific region and broader economic ties with China (Japan). Positioning the Russian Far East as the eastern gateway of Eurasia and the northern gateway of the Indo-Pacific, coupled with the creation of the Vladivostok-Chennai energy and investment axis, by using among other things Japanese technologies, can help develop suitable formats for cooperation between Greater Eurasia and the Indo-Pacific region and boost the development of the Russian Far East (Kupriyanov, 2018).

Secondly, it is important to continue to support ASEAN's central role and to get more engaged in multilateral interaction as a third force that can help ease regional polarization (Istomin, 2019, p. 40). Thirdly, it would be advisable to step up cooperation with Indo-Pacific countries, especially ASEAN states, India, and Japan, in countering various security threats, including non-traditional ones, since this will benefit all countries in the region. Russia and Japan held their first naval anti-piracy exercise in the Arabian Sea in January 2020 (TASS, 2020). This kind of interaction needs to be developed further.

Fourthly, it is necessary to take advantage of the opening opportunities for restructuring regional value-added chains (VAC) in order to localize certain types of production, obtain a number of important technologies, participate in new VACs, and promote Russian products and technologies on the markets of Indo-Pacific developing countries (for example, in the defense, nuclear, oil and gas, chemical industry, metallurgy, and information technologies, including cyber security). Russia is one of the players in the ASEAN infrastructure market, and expanding its presence in the Indo-Pacific region opens up promising prospects for Russian business. One of the interesting options is cooperation with high-tech Japanese companies in third countries, for example, ASEAN and India. 


\section{References}

Abe, S., 2012. Asia's Democratic Security Diamond. Project Syndicate, 27 December. Available at: <https://www.project-syndicate.org/onpoint/astrategic-alliance-for-japan-and-india-by-shinzo-abe> [Accessed 5 May 2020].

Association of Southeast Asian Nations, 2019. ASEAN Outlook on the IndoPacific, 23 June. Available at: <https://asean.org/storage/2019/06/ASEANOutlook-on-the-Indo-Pacific_FINAL_22062019.pdf> [Accessed 5 May 2020].

Center for Strategic and International Studies, 2017. Defining Our Relationship with India for the Next Century: An Address by U.S. Secretary of State Rex Tillerson, 18 October. Available at: <https://www.csis.org/analysis/definingour-relationship-india-next-century-address-us-secretary-state-rex-tillerson> [Accessed 5 May 2020].

Department of Defense, 2013. Defense Paper 2013. Available at: <https://www. defence.gov.au/Whitepaper/2013/docs/WP_2013_web.pdf> [Accessed 5 May 2020].

Department of State, 2019. A Free and Open Indo-Pacific. Advancing a Shared Vision, 4 November. Available at: <https://www.state.gov/wp-content/ uploads/2019/11/Free-and-Open-Indo-Pacific-4Nov2019.pdf> [Accessed 5 May 2020].

Economy, E., 2019. Trade: Parade of Broken Promises. Democracy, 52. Available at: <https://democracyjournal.org/magazine/52/trade-parade-of-brokenpromises/> [Accessed 5 May 2020].

Freeman, C.P. and Oba, M., 2019. Bridging the Belt and Road Divide. Carnegie Endowment for International Peace, 12 October [online]. Available at: $<$ https://carnegieendowment.org/2019/10/10/bridging-belt-and-road-dividepub-80019> [Accessed 5 May 2020].

Green, M.J., 2019. Trump and Asia: Continuity, Change, and Disruption. The Asan Forum, 18 April. Available at: <http://www.theasanforum.org/trump-andasia-continuity-change-and-disruption/> [Accessed 5 May 2020].

Harding, B. 2019. The Trump Administration's Free and Open Indo-Pacific Approach. Southeast Asian Affairs, pp.61-67.

Hosoya, Y., 2019. FOIP 2.0: The Evolution of Japan's Free and Open Indo-Pacific Strategy. Asia-Pacific Review, 26(1), pp.18-28, DOI: 10.1080/13439006.2019.1622868. 
Hudson Institute, 2018. Vice President Mike Pence's Remarks on the Administration's Policy Towards China, 4 October. Available at: <https:// www.hudson.org/events/1610-vice-president-mike-pence-s-remarks-on-theadministration-s-policy-towards-china102018> [Accessed 5 May 2020].

Inhofe, J. and Reed, J., 2020. The Pacific Deterrence Initiative: Peace Through Strength in the Indo-Pacific. War on the Rocks. Available at: <https:// warontherocks.com/2020/05/the-pacific-deterrence-initiative-peace-throughstrength-in-the-indo-pacific/> [Accessed 25 July 2020].

Istomin, I.A., 2019. Politika SShA v Indo-Tihookeanskom regione: posledstviya dlya Rossii [U.S. Policy in the Indo-Pacific: Implications for Russia]. Russian International Affairs Council, Working Paper \#49. Moscow: NP RSMD.

Kawashima, S., 2018. Nicchu kankei "kaizen" e no toi [Japan-China Relations: Issue of "Improvement"], Gaiko, November-December, 52, pp. 28-35.

Kawashima, S., Kamiya, M. and Schoff, J.L., 2019. Managing Risks and Opportunities for the U.S.-Japan Alliance Through Coordinated China Policy. Carnegie Endowment for International Peace, October. Available at: $<$ https:// carnegieendowment.org/2019/10/10/managing-risks-and-opportunities-foru.s.-japan-alliance-through-coordinated-china-policy-pub-80026> [Accessed 5 May 2020].

Khurana, G.S., 2007. Security of Sea Lines: Prospects for IndiaJapan Cooperation. Strategic Analysis, 31(1), pp.139-153. DOI: 10.1080/09700160701355485.

Koga, K., 2020. Japan's 'Indo-Pacific' Question: Countering China or Shaping a New Regional Order? International Affairs, 96(1), pp. 49-73. DOI: 10.1093/ ia/iiz241.

Koldunova, E., 2019. Russia's Ambivalence about an Indo-Pacific Strategy. Asia-Pacific Bulletin, 476, 6 May. Available at: $<$ https://www.eastwestcenter.org/ publications/russia\%E2\%80\%99s-ambivalence-about-indo-pacific-strategy $>$ [Accessed 5 May 2020].

Kupriyanov, A., 2018. The Indo-Pacific Region and Russia. Valdai Discussion Club, 14 November. Available at: $<$ https://valdaiclub.com/a/highlights/the-indopacific-region-and-russia/ $>$ [Accessed 5 May 2020].

Manning, R.A., 2018. U.S. Indo-Pacific Strategy: Myths and Reality. Valdai Papers \#89, July, p.14. 
Ministry of External Affairs, 2018. Prime Minister's Keynote Address at Shangri La Dialogue (June 01, 2018). Available at: <https://www.mea.gov.in/SpeechesStatements.htm?dtl/29943/Prime+Ministers+Keynote+Address+at+Shangri+L a+Dialogue + June $+01+2018>$ [ Accessed 5 May 2020].

Ministry of Foreign Affairs of Japan, 2016. Address by Prime Minister Shinzo Abe at the Opening Session of the Sixth Tokyo International Conference on African Development (TICAD VI), August 27. Available at: <https://www.mofa.go.jp/ afr/af2/page4e_000496.html $>$ [Accessed 5 May 2020].

Ministry of Foreign Affairs of Japan, 2017. Gaiko seisho 2017 [Diplomatic Bluebook 2017], p.339. Available at: <https://www.mofa.go.jp/mofaj/fp/pp/ page23_002228.html> [Accessed 5 May 2020].

Ministry of Foreign Affairs of Japan, 2018. Gaiko seisho 2018 [Diplomatic Bluebook 2018], p.350. Available at: <https://www.mofa.go.jp/mofaj/fp/pp/ page25_001612.html> [Accessed 5 May 2020].

Ministry of Foreign Affairs of Japan, 2019a. Gaiko seisho 2019 [Diplomatic Bluebook 2019], p.379. Available at: <https://www.mofa.go.jp/mofaj/fp/pp/ page22_003299.html> [Accessed 5 May 2020].

Ministry of Foreign Affairs of Japan, 2019b. Japan-AustraliaIndia-U.S. Consultations, 31 May. Available at: <https://www.mofa.go.jp/press/ release/press4e_002464.html> [Accessed 5 May 2020].

Ministry of Foreign Affairs of Japan, 2007. Futatu no imu no majiwari [Confluence of the Two Seas], 22 August. Available at: <https://www.mofa.go.jp/ mofaj/press/enzetsu/19/eabe_0822.html> [Accessed 5 May 2020]

Nakanishi, H., 2018. Nihon gaiko ni okeru "jiyu de hirakareta indo taiheiyo" [Free and Open Indo-Pacific in Japan's Foreign Policy], Gaiko, 52, pp.12-19.

Pajon, C., 2019. Japan's Indo-Pacific Strategy: Shaping a Hybrid Regional Order. War on the Rocks, 18 December. Available at: <https://warontherocks. com/2019/12/japans-indo-pacific-strategy-shaping-a-hybrid-regional-order/> [Accessed 5 May 2020].

Panda, J., 2017. The Asia-Africa Growth Corridor: An India-Japan Arch in the Making? Focus Asia: Perspective \& Analysis, 21, p.11.

President of Russia, 2019. Plenary session of the Eastern Economic Forum, 5 September. Available at: <http://en.kremlin.ru/events/president/news/61451> [Accessed 5 May 2020]. 
President of the United States, 2017. National Security Strategy of the United States of America. December. Available at: <https://www.whitehouse.gov/wp-content/ uploads/2017/12/NSS-Final-12-18-2017-0905.pdf> [Accessed 5 May 2020].

Prime Minister of Japan and His Cabinet, 2014. The 13th IISS Asian Security Summit -The Shangri-La Dialogue. Keynote Address by Prime Minister Abe. 30 May. Available at: <https://japan.kantei.go.jp/96_abe/ statement/201405/0530kichokoen.html> [Accessed 5 May 2020].

Sahashi, R., 2019. The Indo-Pacific in Japan's Foreign Policy. Strategic Japan Working Papers. CSIS. Available at: <https://csis-prod.s3.amazonaws.com/s3fspublic/FINAL_Working\%20Paper_Ryo\%20Sahashi.pdf> [Accessed 5 May 2020].

Shimodaira, T., 2018. Nihon no anzen hosho. Kaiyo anzen hosho to chiiki anzen hosho [Japan's Security. Maritime Security and Regional Security]. Tokyo: Seibundo.

Sutter, R., 2018. US-China Relations. Perilous Past, Uncertain Present. 3rd edition. Lanham: Rowman \& Littlefield.

Suzuki, S. and Wallace, C., 2018. Explaining Japan's Response to Geopolitical Vulnerability. International Affairs, 94[4], pp.711-734. DOI: 10.1093/ia/iiy033.

Szechenyi, N. and Hosoya, Y., 2019. Working Toward a Free and Open IndoPacific. Carnegie Endowment for International Peace. Available at: $<$ https:// carnegieendowment.org/2019/10/10/working-toward-free-and-open-indopacific-pub-80023> [Accessed 5 May 2020]

TASS, 2020. Russia, Japan Kick Off Anti-Piracy Drills in the Arabian Sea. 20 January. Available at: $<$ https://tass.com/defense/1110871 $>$ [Accessed 5 May 2020]

Tellis, A.J., 2020. The Return of U.S.-China Strategic Competition. In: A.J. Tellis, A. Szalwinski and M. Wills (eds.) Strategic Asia 2020. U.S.-China Competition for Global Influence. Seattle and Washington: NBR, pp.3-43.

The Department of Defense, 2019. Indo-Pacific Strategy Report. Preparedness, Partnerships, and Promoting a Networked Region, 1 June. Available at: $<$ https:// media.defense.gov/2019/Jul/01/2002152311/-1/-1/1/DEPARTMENT-OFDEFENSE-INDO-PACIFIC-STRATEGY-REPORT-2019.PDF> [Accessed 5 May 2020].

The Government of Japan, 2019. Towards Free and Open Indo-Pacific. November. Available at: <https://www.mofa.go.jp/files/000407643.pdf> [Accessed 5 May 2020]. 
The Ministry of Foreign Affairs of the Russian Federation, 2016. Foreign Policy Concept of the Russian Federation (approved by President of the Russian Federation Vladimir Putin on November 30, 2016). Available at: <https://www.mid.ru/en/ foreign_policy/official_documents/-/asset_publisher/CptICkB6BZ29/content/ id/2542248> [Accessed 5 May 2020].

The Ministry of Foreign Affairs of the Russian Federation, 2019. Foreign Minister Sergei Lavrov's remarks and answers to media questions during the RussianVietnamese conference of the Valdai International Discussion Club, Ho Chi Minh City, 25 February. Available at: <https://www.mid.ru/en/press_service/minister_ speeches/-/asset_publisher/7OvQR5KJWVmR/content/id/3541050> [Accessed 5 May 2020].

The Ministry of Foreign Affairs of the Russian Federation, 2020. Foreign Minister Sergei Lavrov's remarks and answers to questions at a plenary session of the Raisina Dialogue international conference, New Delhi, January 15, 2020. Available at: <https://www.mid.ru/en/foreign_policy/news/-/asset_publisher/ cKNonkJE02Bw/content/id/3994885> [Accessed 5 May 2020].

The White House, 2017. Remarks by President Trump at APEC CEO Summit. Da Nang, Vietnam. 10 November. Available at: <https://www.whitehouse.gov/ briefings-statements/remarks-president-trump-apec-ceo-summit-da-nangvietnam/> [Accessed 5 May 2020].

The White House, 2020. United States Strategic Approach to the People's Republic of China. May 26. Available at: <https://www.whitehouse.gov/wp-content/ uploads/2020/05/U.S.-Strategic-Approach-to-The-Peoples-Republic-of-ChinaReport-5.24v1.pdf> [Accessed 26 July 2020].

Tsvetov, A., 2018. Indo-Tihookeanskiī front: zachem na geopoliticheskoī karte poyavilsya novyī region i chto eto sulit Rossii? [Indo-Pacific Front: Why Did a New Region Appear on the Geopolitical Map and What Does It Mean for Russia?]. Moscow Carnegie Center, 22 March. Available at: <https://carnegie.ru/ commentary/75706> [Accessed 5 May 2020].

U.S. Department of Defense, 2018. Summary of the 2018 National Defense Strategy of the United States of America. Sharpening the American Military's Competitive Edge. Available at: <https://www.defense.gov/Portals/1/Documents/ pubs/2018-National-Defense-Strategy-Summary.pdf $>$ [Accessed 5 May 2020].

Wallace, C., 2018. Leaving [North-East] Asia? Japan's Southern Strategy. International Affairs, 94(4), pp.883-904. DOI: 10.1093/ia/iiy027. 